\title{
Physical activity of urban adults: a general population survey in Geneva
}

Summary

Objectives: Describing the distribution of physical activity in populations is of major importance for developing public health campaigns to prevent sedentarism:

Methods: 3 population-based survey conducted during $199 \%$ 1999 in Geneva, switzerland, induded 3410 randomly selecred men $(n=1707)$ and women $(n=1703)$, aged 35 to 74 years. Percentiles $10, \mathrm{P50}$, and $\mathrm{P} 90$ summarised the distributions of the rotal energy expenditure and of the percents used in moderate intensiy activities ( 3 to 3.9 times the basal metabolism rate (EMP). e. g. normal walking. household chores), and in high and yery high intensivy activities ( 4 SMR, e.g.s brisk waking, sports :

Results: The total energy expenditure (median $2929 \mathrm{kcal} / \mathrm{day}$ in men, 2212 kallday in women) decreased whth age. Preva lence of secentarism, defined as less than $10 \%$ of total energy expended in $24 \mathrm{BMR}$ activites, was $57 \%$ in men and $70 \%$ in women. Men expended $12 \%$ (median) of their total energy in 3 to 3.9 BMR and $8 \%$ in $\geq 43 \mathrm{MR}$ activites. Corresponding percentages in women were $11 \%$ and $5 \%$. The highest prevalence of sedentarism was in older age, women, and lower socio-ecow nomic status persons.

Conclusion: Most of Geneva population is sedentary. Promot. ing physical ativity should target children, adults and elderly, and physical activities which would be both attractive and financially afrordable by most people.

Key-Words: Energy metabolism - Exercise - Health surveys - Leisure activities - Sports Urban health.
Sedentarism is an independent risk factor for coronary heart disease ${ }^{1-4}$, osteoporosis, hip fractures ${ }^{5-7}$ and cancer ${ }^{8}$. However, the precise amount and intensity of physical activities performed by urban general populations remain elusive.

The total energy expenditure of an individual can be divided into several categories according to the intensity of each activity performed. When sleeping, we expend the basal metabolism rate (BMR). Low intensity activities such as office work, reading, watching television, and walking slowly expend less than 3 times the BMR ( $<3$ BMR). Most household chores and professional activities such as locksmith, handy work, electrician, etc., expend 3 to 3.9 BMR. Expending 4 times the BMR and more ( $\geq 4 \mathrm{BMR}$ ) are gardening activities like digging and carrying loads (4.1 BMR), brisk walking (4.5 BMR), climbing up stairs (6 BMR), heavy construction work (7 BMR), and most sports (6 to 12 BMR). The BMR changes according to gender, age, weight, and height ${ }^{9}$, so for each activity the precise amount of energy expended according to these performer characteristics can be calculated.

The present survey of the general adult population of Geneva describes the total daily energy expenditure, and its distribution in moderate intensity activities ( 3 to $3.9 \mathrm{BMR}$ ), high and very high intensity activities ( $\geq 4 \mathrm{BMR}$ including those $\geq 6 \mathrm{BMR}$ ), and very high intensity activities only ( $\geq 6$ BMR). Physical activity was assessed using a questionnaire developed and validated in the target population ${ }^{10}$. A sedentary person was defined as someone expending less than 10 percent of their daily total energy expenditure in $\geq 4$ BMR physical activities. This definition of sedentarism, developed in a previous paper ${ }^{11}$, was based on the Surgeon General Report suggestion: "an increase in daily expenditure of approximately 150 kilocalories per day is associated with substantial health benefits and the activity does 
not need to be vigorous to achieve benefit" 8 . Because the amount of energy expended depends on the BMR of the person, the duration and the intensity of the activity, we transformed the "150 kilocalories" into a percentage of the total energy expenditure. We also evaluated the risk factors for sedentarism in this generally urban population.

\section{Materials and methods}

\section{Population and sample recruitment}

Geneva (city and county, Switzerland) has a population of about 400000 distributed over $242 \mathrm{~km}^{2}$ of land. Survey participants were randomly selected from January 1997 to December 1999 to represent the 89000 men and 98000 women, non-institutionalised adult residents aged 35 to 74 years. Subjects were identified from the official residents' register published each year which includes the first and last name, gender, age, nationality, and address. About $0.5 \%$ of the target population was sampled each year. Selected men and women received an information letter asking them to participate in a general population health survey ${ }^{12}$. In the case of non-response within two weeks, up to seven phone calls were made at different times of the week including week-ends. Those who could not be contacted after seven attempts were replaced. Systematic checks of the following years' editions of the population list showed that about $90 \%$ of them no longer resided in Geneva. Subjects who refused to participate were not replaced. The recruitment of a potential subject lasted from two weeks to two months.

\section{Data collection}

Survey respondents completed at home self-administered questionnaires about physical activity, diet, and general health including socio-demographic data and smoking history. They returned the questionnaires to a mobile epidemiology clinic where trained interviewers checked them for completion and measured the weight (lightly dressed without shoes) using a medical scale (precision $0.5 \mathrm{~kg}$ ) and the height, using a medical gauge (precision $1 \mathrm{~cm}$ ). Overall, the clinic visit lasted around 20 minutes. Among the persons selected and contacted, the average response rate was $62 \%$, with 1795 men and 1785 women overall participating in the survey. For the purposes of the present report, all analyses were based on the respondents who had complete data for the variables employed in the multiple logistic regression models described below. Thus, the final study sample included 1707 men and 1703 women; its distribution was similar to the general population according to age and gender (data not shown).
Age was categorised into the four groups: $35-44,45-54$, 55-64, 65-74 years. Educational level was defined as primary (< nine years of schooling), secondary, and university (13 or more years and Swiss baccaulaureate or equivalent). Country of birth was grouped into Switzerland, Mediterranean (Italy, Spain, Portugal) and others (mainly France/Germany). Ever cigarette smokers had smoked at least 100 cigarettes in their lifetime. Ex-smokers had quit smoking a year or more before their interview. Body mass index (BMI) was computed as measured weight in kilograms divided by the square of measured height in meters. Normal weight, overweight and obesity were defined respectively as BMI $<25 \mathrm{~kg} / \mathrm{m}^{2} ; 25 \leq \mathrm{BMI}<30 \mathrm{~kg} / \mathrm{m}^{2} ; \mathrm{BMI} \geq 30 \mathrm{~kg} / \mathrm{m}^{2}$.

\section{Diet (food frequency) questionnaire}

This instrument was previously developed and validated in the Geneva general population ${ }^{13,14}$. It records the diet of the past four weeks and lists 80 groups of food items with a "standard" portion size. Respondents indicate their frequency of consumption and if they consumed less, the same, or more, than the standard portion size. Results permit evaluation of the daily total energy intake ( $\mathrm{kcal})$, the percent of the total energy provided by macronutrients, and the amount of dietary fiber $(\mathrm{g})$.

\section{Physical activity frequency questionnaire}

This instrument measures the total daily, and the activityspecific energy expenditures. It was developed in the Geneva general population and validated using a heart rate monitor $^{10}$. It lists 73 physical activities grouped by general type (e.g., occupational, leisure time, sports, etc.), together with their typical duration. The reference period is the past seven days. About 20 minutes are required for respondents to indicate the number of days per week ( 0 (never) to 7 (every day)), and the number of hours per day ( 0 to 10 hours time scale with 15 minute increments) that they spent in performing each activity. The duration of sleep is calculated from the reported waking hours. If the total number of hours declared by the respondent is different from 168 hours $(7 x$ 24 hours), a two step correction is made. First, if the duration of sleep is less than 42 hours (six hours per night), it is set to 42 hours; or if it is more than 70 hours (ten hours per night), it is set to 70 hours. (About $2.5 \%$ of the initially calculated durations of sleep fell in each of these extremes). Second, the total duration for non-sleep activities is calculated and the duration for each non-sleep activity is proportionally adjusted so that the corrected duration of sleep plus the non-sleep duration sums to 168 hours. Each listed physical activity was pre-assigned a score indicating its intensity in terms of BMR multiples ${ }^{9}$. For example, an activity with a 
3 BMR rating expends three times the energy required by a fasting individual, sleeping. The gender, age, and weight/ height-specific BMR was calculated for each study respondent ${ }^{9}$.

The daily energy expenditure for a given activity, $E E_{\mathrm{i}}$ for activity $i, i=1, \ldots 73$, for a particular study participant was next calculated as:

\section{$E E_{\mathrm{i}}=(\mathrm{BMR}$ multiple for activity) i) $\mathrm{X}$ (duration of activity $i$, in minutes per day) $X$ (BMR of participant in kcal per minute).}

The daily total energy expenditure, $E E$, for the study participant was then obtained as the sum of the study participant's activity-specific $E E_{\mathrm{i}}$ over all 73 physical activities:

$$
E E=\sum_{\mathrm{i}=1}^{73} E E_{\mathrm{i}} .
$$

The various physical activities were grouped according to their intensity. The two main categories were: 1 ) Moderate intensity activities expending 3 to 3.9 times the BMR such as most housekeeping chores, walking normally, and bicycling slowly (about $9 \mathrm{~km} / \mathrm{h}$ );2) High and very high intensity activities expending $\geq 4$ times the BMR such as walking quickly or uphill (4.5 BMR), climbing stairs (6 BMR), sports and heavy construction work ( $\geq 6 \mathrm{BMR}$ ). We also analysed separately the contribution of very high intensity activities ( $\geq 6 \mathrm{BMR}$ ) such as sports and heavy construction work.

\section{Statistical analyses}

Summaries of the distributions of the categorical or grouped study variables described in the previous section were made in terms of percentages. Percentiles (P10, P50 (median), $\mathrm{P} 90$ ) with $95 \%$ nonparametric confidence intervals $(\mathrm{Cl})^{12}$ by age groups for continuous variables related to total energy expenditure were depicted in two dimensional figures. Supplementary tables given in the appendix report the percentiles $\mathrm{P} 10, \mathrm{P} 25, \mathrm{P} 50, \mathrm{P} 75, \mathrm{P} 90$, as well as the mean and standard deviation (SD).

Multiple logistic regression models ${ }^{15}$ were employed to evaluate the relationship between sedentarism and sociodemographic variables, with adjustment for the potential confounders age, education level, country of birth, cigarette smoking, dietary fat, and dietary fiber. The logistic analyses were performed separately for men and for women. The magnitudes of the associations between the sedentary versus active dependent variable and the risk factor independent variables were evaluated with odds ratios ( $O R$ ) obtained by exponentiating the corresponding logistic regression coeffi- cients, together with $95 \%$ Wald confidence intervals $(\mathrm{Cl}=$ exponentiated $\mathrm{Cl}$ for $\log \mathrm{OR}$ ). All models were checked for goodness-of-fit with the Hosmer-Lemeshow test; no inadequate fits were found (for men and women, respective $p>$ 0.11 and $p>0.61$ ).

\section{Results}

\section{Sample characteristics}

Prevalence of sedentarism was $57 \%$ in men and $70 \%$ in women (Tab. 1). Duration of sleep did not decrease with age. The proportions of obesity and overweight were respectively $13 \%$ and $45 \%$ in men and $9 \%$ and $24 \%$ in women. The majority of the men and women had a secondary level education and were Swiss. Only $27 \%$ of the men and $22 \%$ of the women were current smokers.

\section{Physical activity distributions}

Percentiles P10, P50 (median), and P90 (with $95 \% \mathrm{Cl}$ ) of the total energy expended per day by age groups, are displayed in Figure 1. Percentiles 10 and 90 respectively, can be interpreted as follows: for example, for men, ages $35-44$, only $10 \%$ of them expend $2526 \mathrm{kcal}$ per day or less (the lowest $10 \%$ ), and only $10 \%$ of them expend more than $3992 \mathrm{kcal}$ per day (the highest $10 \%$ ). Total energy clearly declines with age in men, the median showing a $500 \mathrm{kcal}$ reduction in the oldest group (2461 kcal per day, age 65-74) compared to the youngest ( $3050 \mathrm{kcal}$ per day, age $35-44)$. This decrease

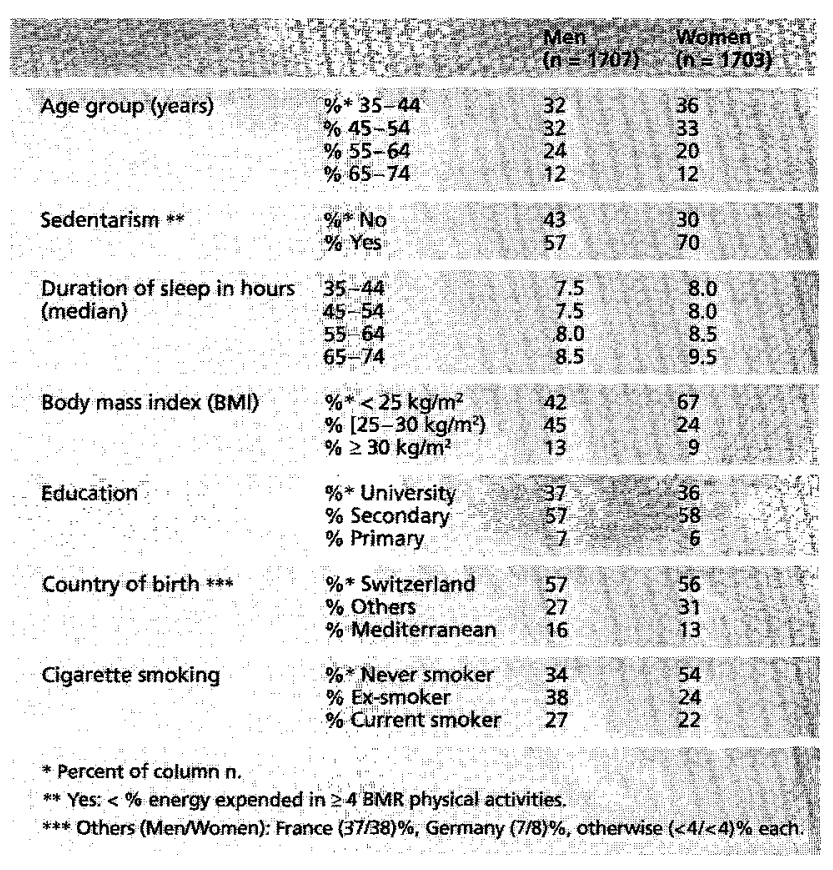

Table 1 Characteristics of study participants. Geneva, 1997-1999 


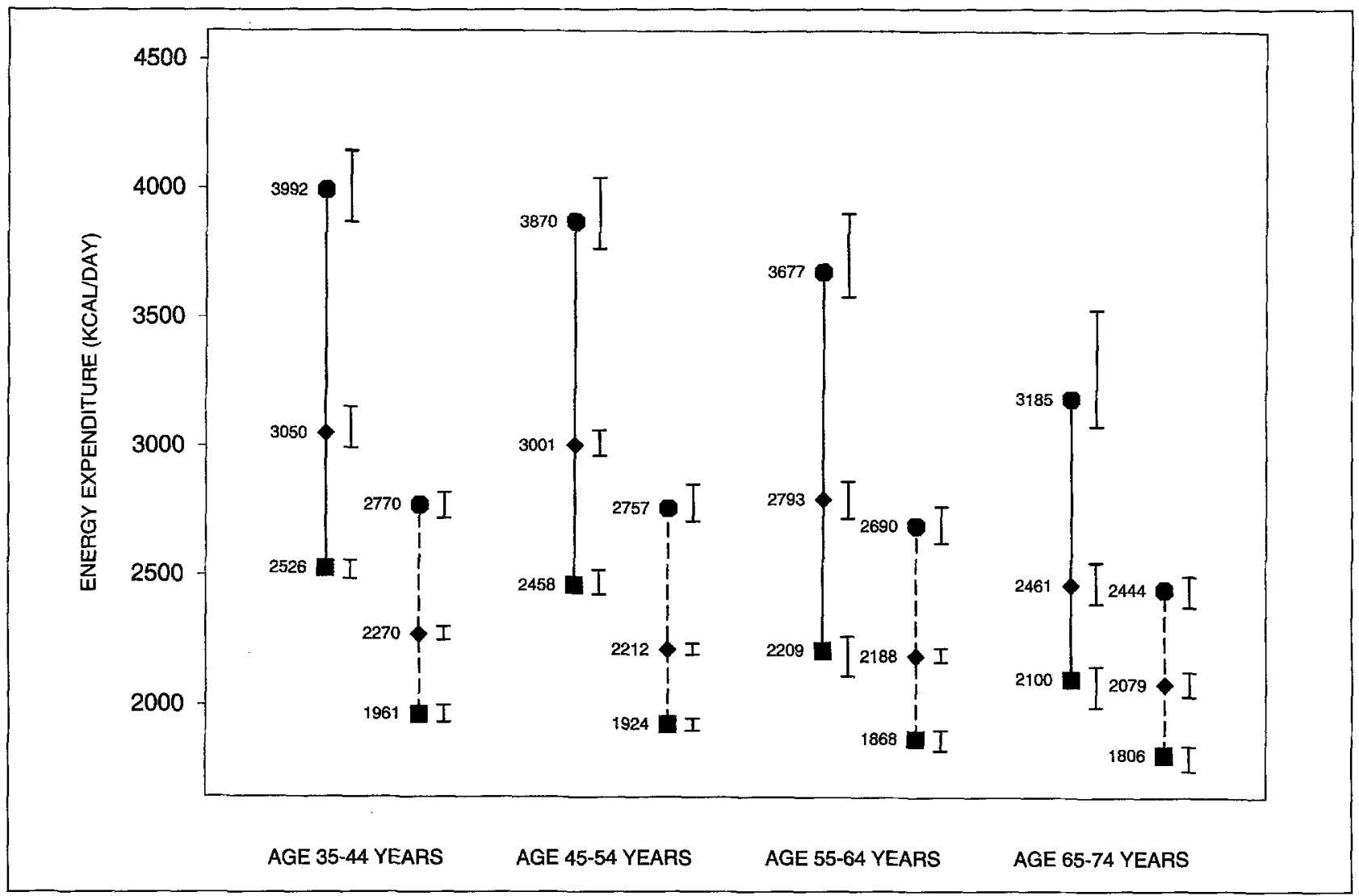

Figure 1 Total energy expenditure, according to gender and age groups. Square $=\mathrm{P} 10$, Diamond $=\mathbf{P 5 0}$, Octagon $=\mathrm{P90} ;$ Solid lines $=$ Men, Dashed lines $=$ Women. Solid lines with crossbars to right of symbols $=95 \%$ confidence intervals

according to age is much smaller in women with only a $200 \mathrm{kcal}$ reduction between the same age groups. Within each age group, a wider dispersion is seen in men (about $1500 \mathrm{kcal}$ of difference between the percentile P10 and the percentile $\mathrm{P} 90$ ) compared to women (only $800 \mathrm{kcal}$ of difference).

Distributions by age groups of the percents of total energy expended in moderate activites ( 3 to $3.9 \mathrm{BMR}$, such as walking normally) had no clear relationship with age: the percentile $\mathrm{P} 10$ and the median but not the percentile P90, seem to be increasing only after age 55 (Fig. 2 and Appendix).

In Figure 3, percentile P10 equals zero for all age groups, which means that at least $10 \%$ of men and women did not perform any high or very high intensity activities ( $\geq 4$ BMR) such as brisk walking ( $4 \mathrm{BMR}$ ), stairs (6 BMR), sports ( $\geq 6$ BMR). The median and the percentile P90 are decreasing with older age in both genders. While half the men in the youngest group expend less than $10 \%$ (median) of their energy in such activities, half the 65-74 year old men expend only $2.5 \%$ (median) in these types of activities. In women, the corresponding medians decrease from $5.8 \%$ in the youn- gest to $1.5 \%$ in the oldest group. The percentile $\mathbf{P} 90$ is the point above which the $10 \%$ most active respondents are. Among the $10 \%$ most active men, $\geq 4$ BMR activities represent about $30 \%$ or more of the daily energy expenditure in all age groups. In comparison, the $10 \%$ most active women only expend $22.1 \%$ (35-44 years old) to $15.8 \%$ (65-74 years old) in $\geq 4$ BMR activities.

In all age groups, the majority of people perform not very high intensity activities ( $\geq 6 \mathrm{MBR}$ ) (median $=0 \%$; shown in Appendix). In the Geneva population, these activities mainly include sports, with only a few men also performing occupations like very hard construction work. The percentiles

Figure 2 Percent of total energy expended in 3-3.9 BMR activities, according to gender and age groups. Square $=P 10$,Diamond $=P 50$, Octagon $=$ P90; Solid lines $=$ Men, Dashed lines $=$ Women. Solid lines with crossbars to right of symbols $=95 \%$ confidence intervals

Figure 3 Percent of total energy expended in $\geq 4$ BMR activities, according to gender and age groups. Square $=\mathrm{P} 10$, Diamond $=\mathrm{P} 50$, Octagon = P90; Solid lines $=$ Men, Dashed lines $=$ Women . Solid lines with crossbars to right of symbols are $95 \%$ confidence intervals 

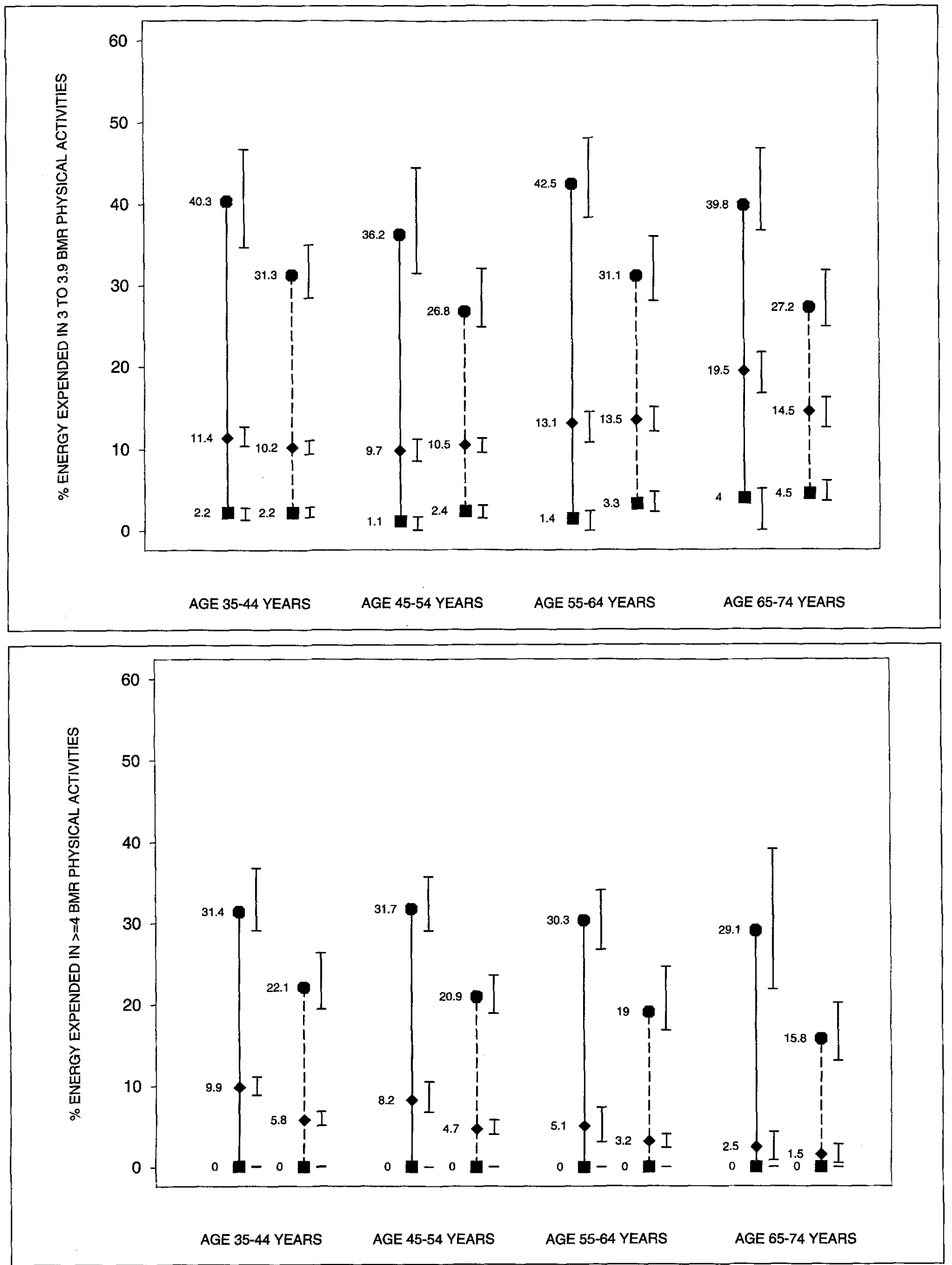


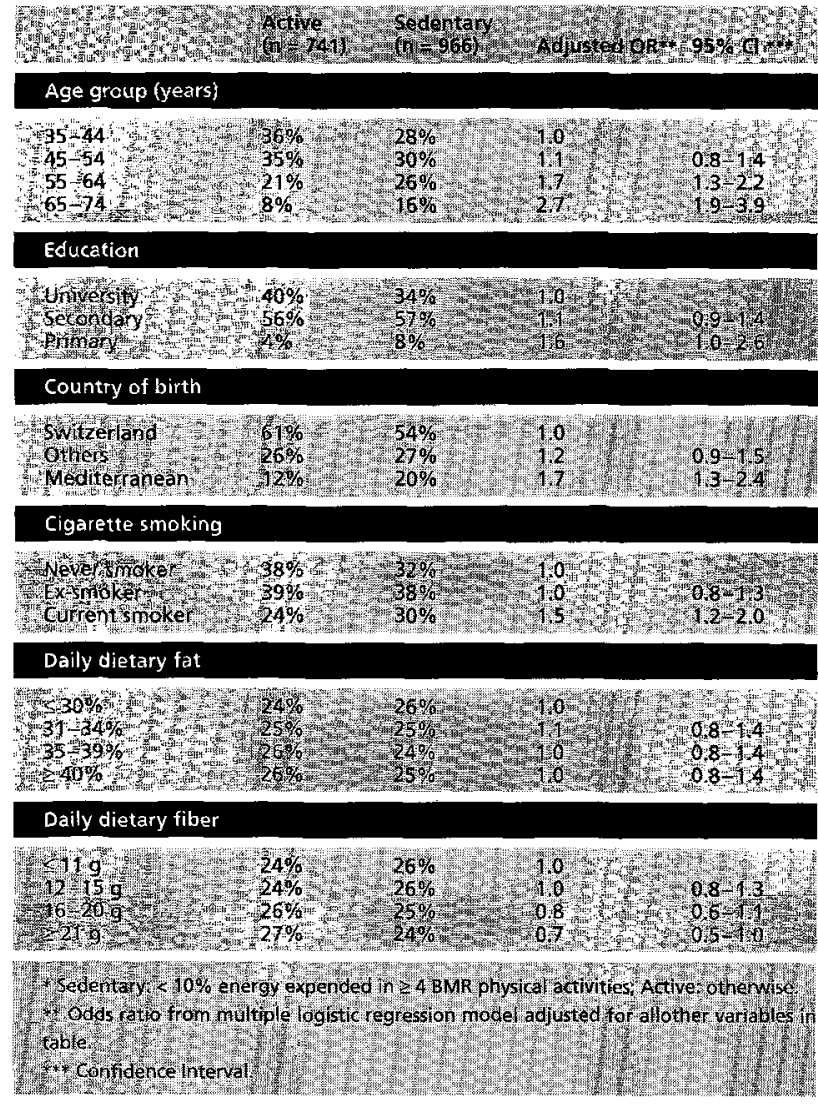

Table 2 Odds ratios of being sedentary* versus active*, in men ( $n=$ 1707), according to several risk factors. Geneva, 1997-1999

P90 show that the $10 \%$ most active men expend about $16-23 \%$ of their energy in very high intensity activities and these percentages seem to remain identical with older age. In women however, the most active $10 \%$ expend only about $10-12 \%$ of their energy in very high intensity activities in the two youngest groups, but this percentage decreases to about $3-7 \%$ for the two oldest groups.

\section{Correlates of sedentarism}

Sedentarism increases with age in both genders (Tab. 2 and 3). A lower (primary) education, being born in Mediterranean countries, and being a current smoker increase the risk of sedentarism in men. Only a lower (primary) education and being born in Mediterranean countries, but not smoking, increase by two-fold the risk of being sedentary in women. Dietary fiber seems to be related to a lower risk of sedentarism, more in women $(\mathrm{OR}=0.5,95 \% \mathrm{Cl}=0.3-0.6)$ than in men $(\mathrm{OR}=0.7,95 \% \mathrm{Cl}=0.5-1.0)$.

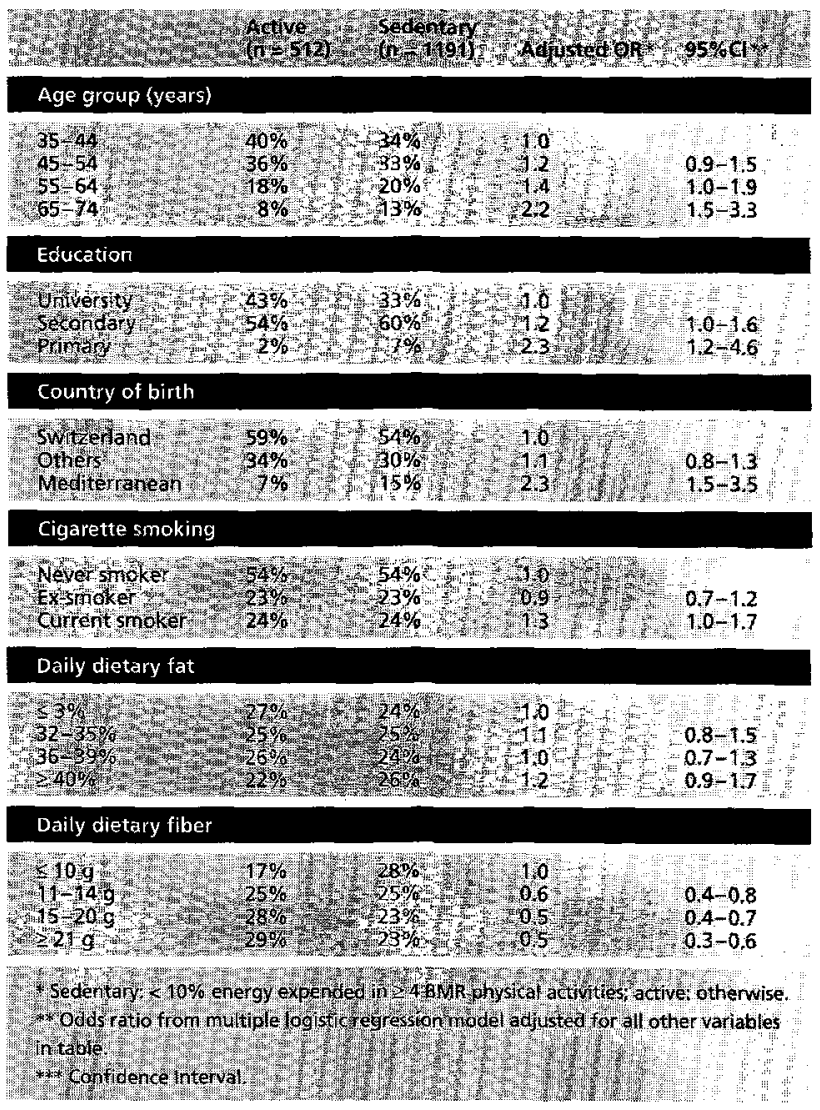

Table 3. Odds ratios of being sedentary* versus active*, in women ( $n=$ 1703), according to several risk factors. Geneva, 1997-1999

\section{Discussion}

To our knowledge, this is the first time that the amount of total energy expenditure and its components, that is the several intensity levels of physical activities, are described in a general population. The major finding is the low prevalence of high and very high intensity activities ( $\geq 4 \mathrm{BMR}$ ) such as brisk walking (4 BMR), climbing stairs (6 BMR), and sports $(\geq 6 \mathrm{BMR})$. Indeed, more than $10 \%$ of men and women are not performing any of these activities. For half of the population, these activities represent $10 \%$ or less in men and $7 \%$ or less in women, of the total energy expenditure; these proportions clearly decrease with older age. According to our definition, the prevalence of sedentarism is very high in Geneva $(57 \%$ in men and $70 \%$ in women),

In a recent Swiss national survey ${ }^{16}, 500$ Swiss adults were interviewed on the telephone about their usual activities relative to current recommendations. Results showed that $26 \%$ of the population reported performing at least 30 minutes per day of $\geq 4$ BMR activities such as brisk walking and $37 \%$ of the population reported performing sports at least 3 times per week. The differences with the Geneva results may 
be explained partly by the different methods used: the Swiss survey also included 15-24 and 25-34 year old people, who are more active than older individuals. On the phone, the interviewees were asked to evaluate the intensity of the activities performed and therefore they may have overestimated it. With the Geneva questionnaire, the interviewees responded to a list of activities without knowing how the intensity was rated. If we assume that only individuals reporting performing sports in the national study $(37 \%$ of the interviewees) are not sedentary, then the national and Geneva results agree fairly well that the prevalence of sedentarism is about $60 \%$ in Switzerland.

The high prevalence of sedentarism may be related to the current epidemics of obesity and overweight in western countries $^{17.19}$ with their dramatic consequences ${ }^{19-22}$. The association between sedentarism and obesity ${ }^{23-25}$ and the protective effect of physical activity ${ }^{25-29}$ are well established. Prevalence of obesity and overweight in Geneva are, respectively, $13 \%$ and $45 \%$ in men and $9 \%$ and $24 \%$ in women Diet cannot be the only reason for these high prevalences since total energy intake and proportion of fat in the diet have been decreasing in the recent past ${ }^{30,31}$.

In the present results, sedentarism seems to be associated with country of birth. This is also true for other coronary heart disease risk factors as, for example, Italian-born women have a higher prevalence of overweight and obesity than Swiss women ${ }^{18}$. Country of birth may reflect behaviours, genetic factors, cultural habits, and social status. Education is also inversely and independently related to sedentarism. These results are consistent with the Swiss national survey (OFSP) which showed that differences linked to gender, age and socio-economic status are currently increasing.

The present sample has a rather low proportion of current smokers, and a high educational status; these results have been very consistent in the Geneva population since $1992^{32}$. A selection bias with respondents being more aware of health issues compared to the general population cannot be completely excluded, but in that case, the prevalence of sedentarism would be underestimated in the present report. The majority of the Geneva general population did not per- form any very high intensity activities, mainly including sports. The prevalence is clearly decreasing with older age. Some elderly people may not be aware of their physical capabilities and the fun they may expect to derive from performing sports.

Promotion of high intensity activities (such as brisk walking) and sports should therefore focus not only on adults but also on children (to compensate for the effect of having a lower education), and on older people. Bicycling has been found to be one of the Geneva active people's favorite activities ${ }^{10,11}$. Depending on the speed, it may be a sport but also an activity of $\geq 4$ BMR which could be performed on an everyday basis, by most people. However, activities on public streets, such as walking and bicycling, are also associated with exposure to traffic accidents, especially for children and elderly people who are often compromised in sight, hearing, reaction time and muscle strength. Indeed, the strong support of the public authorities is necessary to promote both physical activity and security for all.

\section{Conclusion}

The majority of men and women in Geneva are sedentary. They perform no sports and few high intensity activities. Sedentarism is even more prevalent in older age, women and lower socio-economic status persons, as people from the highest socio-economic status are better informed about the importance of physical activity and have more resources to perform sports. Promoting physical activities therefore needs to target on children, adults and elderly, and on physical activities which would be both attractive and financially affordable by most people. Brisk walking, using stairs and bicycling are smart choices but need to be motivated and stimulated by major health promotion interventions. Activities on public streets require strong political support for making them safe and feasible throughout the city.

\section{Acknowledgement}

This study was supported by the Swiss National Fund for Scientific Research, grant no. 32-54097.98. 
Zizsammenfassung

Die körperliche Aktivität der erwachsenen Allgemeinbevölkerung: eine Erhebung in Genf

Fragestellung: Die Beschreibung der Verteilung der körpenli chen Aktivitat in der Bevolkerung is von grosser Bedeuturg stur die šftentiche Gesundheitsplego.

Methoden: Eine von $199 \%$ - 1999 in der schweiz durchgeführte Ehebung auf Bevolkerungsebene erhaste mit 1707 Männer und 1703 Frawen eine Zufallsstichprobe der 35 -bis 74 -jâhrigen Genfer Bevökerung. Die 10\%- 50\% (Median) und $90 \%$-Perzentile dienen zur Beschreibung der vertelung des gesemten Energieverbrauchs und der Antella davon, die für moderate Aktivitäten (z.B. normales Laufen. Haushalsarbeiten), weiche 3- bis $3,9 m a l$ den Gundumsetz (GU) yerbrauchen sowe für intensive und hochintensive Aktivitaten $\geq 4 \mathrm{GU}, 2.8$. schnelles Laufen, Treppenstelgen, 5nory aufgewender wholen.

Ergebnisse: Der Gesamtenergievarbrauch (Median Männer $2929 \mathrm{kcal} / \mathrm{Tag}$, Frauen $2212 \mathrm{kcal} / \mathrm{Tag}$ ) sank bei beiden Geschlechtem mit zunehmendem Atter bie Pravalenz der sitzenden Lebensweise, definert als weniger als $10 \%$ des Gesamtenergieverbrauchs durch Aktivituten von $\geq 4$ GU, betrug bei den Männern $57 \%$ und bei den Frauen $70 \%$. Die Männer verbrauchten $12 \%$ ihrer Gesamtentergie mit Aktiväten von $3-3,9$ GU und $8 \%$ mit Aktivitaten von $\geq 4 \mathrm{GU}$. Die entsprechenden Privalenzen bel den Frauan betrugen $11 \%$ und $5 \%$ Die wenigen Mannar (43\%) und Frasen (31\%) die hochintorsive Aktivitaten ausubten (Sport oder berufluhe Tatigkeiten $\geq 6$ GU), verbrauchten im Durchschnitt $15 \%$ respektive $9 \%$ ihres Gesamtenergieverbrauchs durch diese Aktivitäten. Das Alter, Geschlecht, Herkuntsland, Geburtsland und die Ausbuldung sind statistisch signifikante Einflussfaktoren für die Sthwere der körperlichen Aktivitžt

Schlussfolgerungen: Diese Erhebung zeigt, dass der Grosstell der Genfer Erwachsenen einen sitzencen Lebensstil pllegt und wenig oder keine Energie mit intensiven oder hochintensiven Aktivitaten werbraucht.
Résumés

L'activité physique de la population générale adulte: une enquête à Genève

Objectifs: a description de la distribution de l'activité physique dans la population est dune impontance promordiale pour la santé publingue.

Méthodes: En 1997-1999, Genève, Sursse, cette enquête a indus 1707 hommes ex 1703 femmes sélectionnés au hasard dans la population générale âgée de 35 74 ans. Les percentiles P10, P50 (médiane) et p9o résument listribution de lénergi totale dépensée, et des proportions de cette énergie untiliśces en activités modérées ( 3 à 3,9 foís le métabolisme de base [MB!, ex., marche nomale, activités ménagères) et en accivités intenses ou très intenses $\geq 4 \mathrm{MB}, \mathrm{ex}$, marche rapide, sports:.

Résultats: L'énergie totale dépensée (médiane $2,929 \mathrm{kral} / \mathrm{k}$ chez les hommes, $2,212 \mathrm{kcal} / \mathrm{j}$ chez les femmes) décroit avec lâge. La prévalence de la sédentantá, définie comme moins de $10 \%$ de l'énergie totale dépensếe dans les activités de $\geq 4$ MU, ast de $57 \%$ chez les hommes et $70 \%$ chez les femmes. Les hommes dépensent $12 \%$ de leur énergle totale dans des actuvî́s de $3-3,9$ MB et $8 \%$ dans des activités de $\geq 4$ MB. Ces prévalences sont de $11 \%$ et $5 \%$ chez les femmes. La sédentarite esấ ancore plus fréquente chez les femmes, les personnes agées et de bas niveau de scolarité.

Conclusions: La majonté des Genevois est sédentaire. Promouvoir l'activité physique doit cibler les entants, les adutes et les personnes ägées, en préférant les activités simples et financièrement abordables pour tous. 


\section{TReferences}

1 Stampfer MJ, Hu FB, Manson JE, Rimm $E B$, Willett WC. Primary prevention of coronary heart disease in women through diet and lifestyle. N Engl J Med 2000; 343 : 16-22.

2 Sesso HD, Paffenbarger RS Jr, Lee IM. Physical activity and coronary heart disease in men: The Harvard Alumni Health Study. Circulation 2000; 102: 975-80.

3 Kaprio J, Kujala UM, Koskenvuo M, Sarna $S$. Physical activity and other risk factors in male twin-pairs discordant for coronary heart disease. Atherosclerosis 2000; 150 : 193-200.

4 Manson JE, HU FB, Rich-Edwards JW, et al. A prospective study of walking as compared with vigorous exercise in the prevention of coronary heart disease in women. $\mathrm{N}$ Engl J Med 1999; 341: 650-8.

5 Layne JE, Neison ME. The effects of progressive resistance training on bone density: a review. Med Sci Sports Exerc 1999; 31: $25-30$.

6 Coupland CA, Cliffe SJ, Bassey EI, Grainge $M J$, Hosking $D J$, Chilvers $C E$. Habitual physical activity and bone mineral density in postmenopausal women in England. Int J Epidemiol 1999; 28: 241-6.

7 Gregg EW, Pereira MA, Caspersen CJ. Physical activity, falls, and fractures among older adults: a review of the epidemiologic evidence. J Am Geriatr Soc 2000; 48: 883-93.

8 Physical activity and health. A report of the surgeon general. Atlanta, GA: US Department of Health and Human Services, National Center for Chronic Disease Prevention and Health Promotion, 1996.

9 WHO consensus report on "Energy and protein requirements." Geneva: World Health Organization, 1986. (WHO technical report; no 724).

10 Bernstein $M$, Sloutskis D, Kumanyika $S$, Sparti A, Schutz Y, Morabia A. Data-based approach for developing a physical activity frequency questionnaire. Am J Epidemiol 1998; 147: 147-54

11 Bernstein MS, Morabia A, Sloutskis D. Definition and prevalence of sedentarism in an urban population. Am J Public Health 1999; 89: 862-7.
12 Morabia A, Bernstein MS, Heritier S, Ylli $A$. Community-based surveillance of cardiovascular risk factors in Geneva: methods, resulting distributions and comparisons with other populations. Prev Med 1997;26: 311-9.

13 Bernstein $M$, Morabia A, Costanza $M C$, et al. Equilibre nutritionnel de l'alimentation de la population adulte résidant à Genève. Soz Praventivmed 1994; 39: 333-44.

14 Morabia A, Bemstein M, Kumanyika S, et al. Développement et validation d'un questionnaire semi-quantatif à parti d'une enquête de population. Soz Praventivmed 1994; 39:345 69.

15 Hosmer D, Lemeshow S. Applied logistic regression. New York: J. Wiley, 1989.

16 Martin B, Lamprecht $M$, Calmonte $R$, Raeber $B$, Marti $B$. Taux d'activité physique de la population suisse: niveaux et effets sur l'état de santé. Bull office fédéral santé publique 47 ( 20 nov 2000).

17 Mokdad AH, Serdula MK, Dietz WH, Bowman BA, Marks JS, Koplan JP. The spread of the obesity epidemic in the United States, 1991 - 1998. JAMA 1999; 282: 1519-22.

18 Morabia A, Beer-Borst S, Hercberg S. Locally based surveys, unite! The EURALIM example. AM J Public Health 1998; 88: 1199-202,

19 Allison DB, Fontaine $K R$, Manson JE, Stevens J, Van Itallie TB. Annual deaths attributable to obesity in the United States. JAMA 1999; 282: 1530-8.

20 Lee IM, Manson IE, Hennekens CH, Paffenbarger $R S J r$. Body weight and mortality. A 27-year follow-up of middle-aged men. JAMA 1993; 270: 2823-8.

21 Fine JT, Colditz GA, Coakley EH, et al. A prospective study of weight change and health-related quality of life in women. JAMA 1999; 282: 2136-42.

22 Paffenbarger RS Ir, Hyde RT, Wing AL, Lee IM, Jung DL, Kampert JB. The association of changes in physical-activity level and other lifestyle characteristics with mortality among men. N Engl J Med 1993; 328: $538-45$.

23 Martinez-Gonzalez MA, Martinez JA, Hu $F B$, Gibney MJ, Kearney J. Physical inactivity, sedentary lifestyle and obesity in the European Union. Int J Obes Relat Metab Disord 1999; 23: 1192-201.
24 French $S A$, Jeffery $R W$, Forster $J L$, $M c$ Govern $P G$, Kelder SH, Baxter JE. Predictors of weight change over two years among a population of working adults: the Healthy Worker Project. Int J Obes Relat Metab Disord 1994; 18: 145-54.

25 Di Pietro L, Williamson DF, Caspersen CJ, Eaker $E$. The descriptive epidemiology of selected physical activities and body weight among adults trying to lose weight: the Behavioral Risk Factor Surveillance System survey, 1989. Int J Obes Relat Metab Disord 1993; 17:69-76.

26 Pate $R R$, Pratt $M$, Blair $S$, et al. Physical activity and public health. A recommendation from the Centers for Disease Control and Prevention and the American College of Sports Medicine. JAMA 1995; 273: 402-7.

27 Hunter GR, Weinsier RL, Bamman MM, Larson $D E$. A role for high intensity exercise on energy balance and weight control. Int J Obes Relat Metab Disord 1998; 22: 489-93.

28 Khalid ME. The association between strenuous physical activity and obesity in a high and low altitude populations in southern Saudi Arabia. Int J Obes Relat Metab Disord 1995; 19: 776-80.

29 Tremblay A, Despres JP, Leblanc C, et al Effect of intensity of physical activity on body fatness and fat distribution. Am J Clin Nutr 1990; 51: 153-7.

30 Heini $A F$, Weinsier $R L$. Divergent trends in obesity and fat intake patterns: the American paradox. Am J Med 1997; 102: 259-64.

31 Prentice AM, Jebb SA. Obesity in Britain: gluttony or sloth? BMJ 1995; 311: 437-9.

32 Morabia A, Bernstein MS, Heritier S, Beer-Borst $S$. A Swiss population-based assessment of dietary habits before and after the March 1996 "mad cow disease" crisis. Eur J Clin Nutr 1999; 53: 158-63.
Dr. Martine S. Bernstein Division d'Epidémiologie Clinique Hôpitanx Universitaires de Genève 25 rue Micheli-du-Crest 1211 Geneva 14 Switzerland

Tel.: +41-22 3729554 


\section{Appendix}
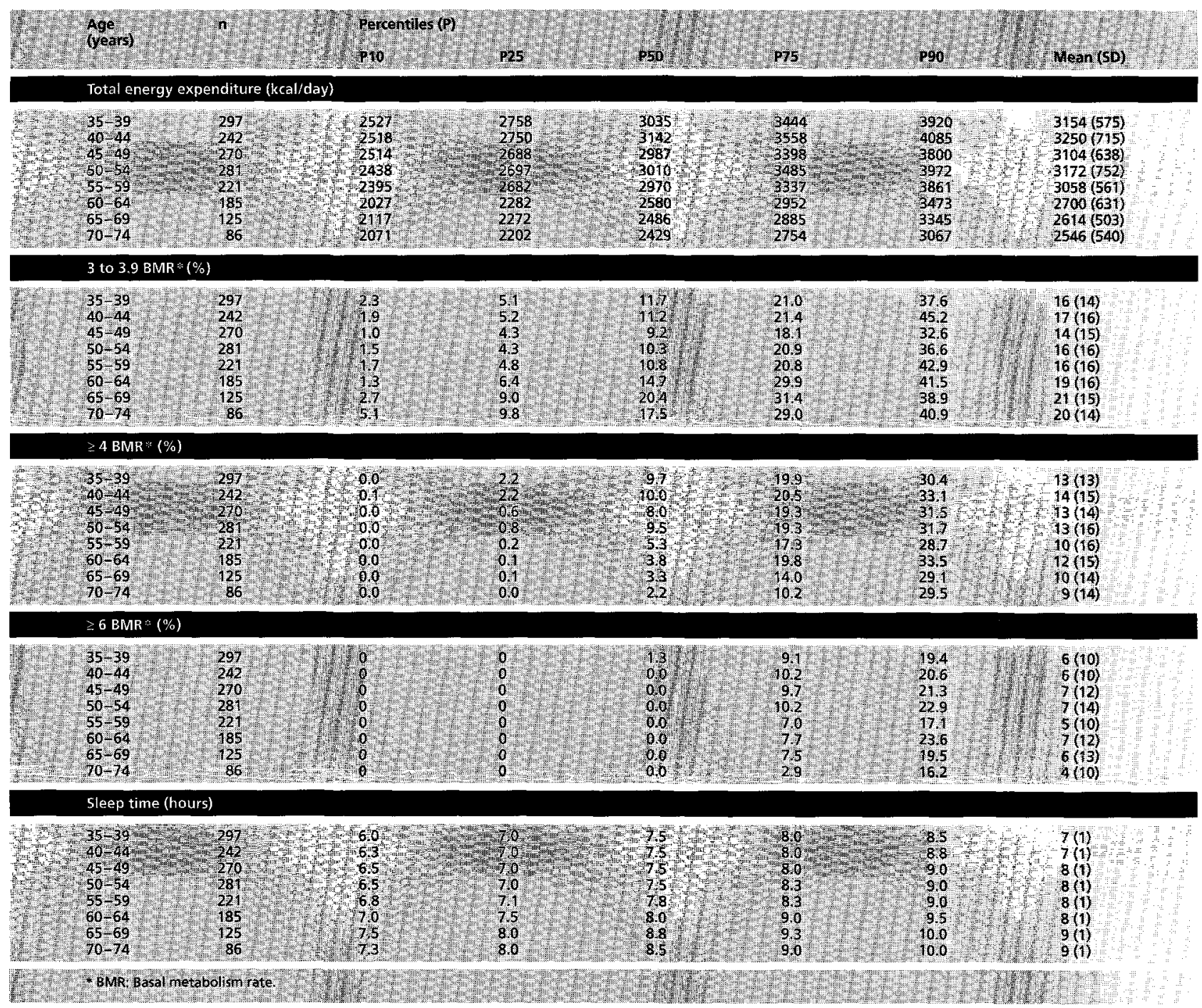

Table A1 Physical activity in men ( $n=1707)$. Geneva, $1997-1999$.

Total energy expenditure and its distribution in moderate intensity activities ( 3 to 3.9 BMR*), high intensity activities $\left(\geq 4 \mathrm{BMR}^{*}\right)$ and very high intensity activities $\left(\geq 6 \mathrm{BMR}^{*}\right)$. 


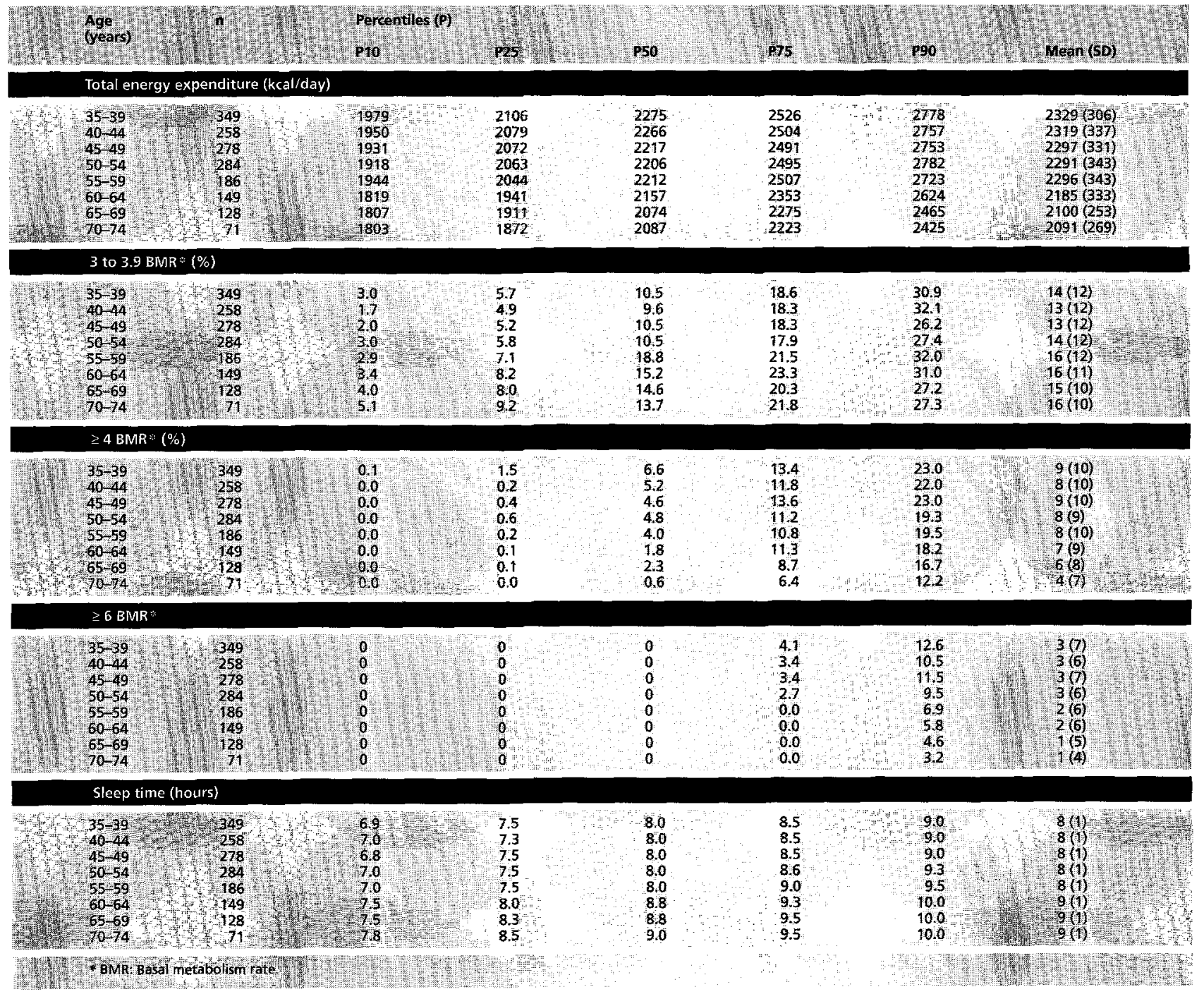

Table A2 Physical activity in women ( $n=1703)$. Geneva, 1997-1999

Total energy expenditure and its distribution in moderate intensity activities ( 3 to $3.9 \mathrm{BMR}$ ), high intensity activities $(\geq 4 \mathrm{BMR}$ ) and very high intensity activities ( $\left.\geq 6 \mathrm{BMR}^{*}\right)$. 